\title{
Step(pe) up! Raising the profile of the Palaearctic natural grasslands
}

\author{
Péter Török ${ }^{1} \cdot$ Didem Ambarlı $^{2} \cdot$ Johannes Kamp $^{3}$. \\ Karsten Wesche $^{4,5} \cdot$ Jürgen Dengler ${ }^{6,5}$
}

Published online: 26 September 2016

(C) Springer Science+Business Media Dordrecht 2016

\begin{abstract}
Palaearctic steppes are primary grasslands dominating the landscape of the Eurasian Grassland Belt from Central and Eastern Europe to Northern China across the temperate zone of Eurasia. We also include structurally and floristically similar habitats in North Africa, Anatolia, and Iran. The biota of the steppes are diverse, including many endemic species. As a result of the high rate of anthropogenic conversion and widespread degradation, the Palaearctic steppes have become one of the most endangered terrestrial biomes of the world. These facts underline the importance of sustaining landscape-scale biodiversity in steppes and stress the necessity of their conservation and restoration. Literature about the ecology, biodiversity, and conservation of Palaearctic steppes is not easily accessible for an international audience. Therefore, summarising the current state of knowledge as well as knowledge gaps is very timely. This Special Issue on "Palaearctic steppes: ecology, biodiversity and conservation", comprises 17 research papers from many different regions throughout the biome, as well as a broad review synthesising current knowledge.
\end{abstract}

Keywords Biodiversity · Eurasia · Eurasian Dry Grassland Group (EDGG) · Grassland conservation $\cdot$ Land use $\cdot$ Steppe biome

Péter Török

molinia@gmail.com

1 MTA-DE Biodiversity and Ecosystem Services Research Group, Egyetem Square 1, Debrecen 4032, Hungary

2 Faculty of Agriculture and Natural Sciences, Düzce University, Konuralp, 81620 Düzce, Turkey

3 Institute of Landscape Ecology, University of Münster, Heisenbergstr. 2, 48149 Münster, Germany

4 Senckenberg Museum of Natural History Görlitz, P.O. Box 300154, 02806 Görlitz, Germany

5 German Centre for Integrative Biodiversity Research (iDiv) Halle-Jena-Leipzig, Deutscher Platz 5e, 04103 Leipzig, Germany

6 Plant Ecology, Bayreuth Center of Ecology and Environmental Research (BayCEER), University of Bayreuth, Universitätsstr. 30, 95447 Bayreuth, Germany 


\section{Introduction}

The Palaearctic steppes form one of the largest continuous terrestrial natural habitats of the world. Their primary grasslands dominate the Eurasian Grassland Belt from Eastern Central Europe to Northern China across the temperate zone of Eurasia (Fig. 1). Steppes (in the wider sense) are also found in North Africa, Anatolia, and Iran (Wesche et al. 2016). Zonal steppes are generally treeless because of climatic aridity and/or rapid drainage of soil. In the forest-steppe zone, the mosaic character of the landscape with grasslands interspersed by scattered groups of trees and small woods is usually maintained by the grazing of domestic and wild ungulates and wildfires, which all prevent the establishment of extensive closed forests (Bredenkamp et al. 2002). Steppes are diverse in their abiotic conditions as well as their biotic composition, and they sustain a high number of endemic species (Dengler et al. 2014; Kajtoch et al. 2016). As typical steppes are characterised by fertile soils (often Chernozems), large areas of steppes have been converted to croplands in Europe and parts of Asia. Large-scale conversion started early in Europe, and by the end of the 19th century, most of the steppes of Eastern Europe (including Ukraine and European Russia) had been converted into cropland (Wesche et al. 2016). Across the Siberian and Central Asian steppes, the Virgin Lands Campaign of the Soviet Union led to

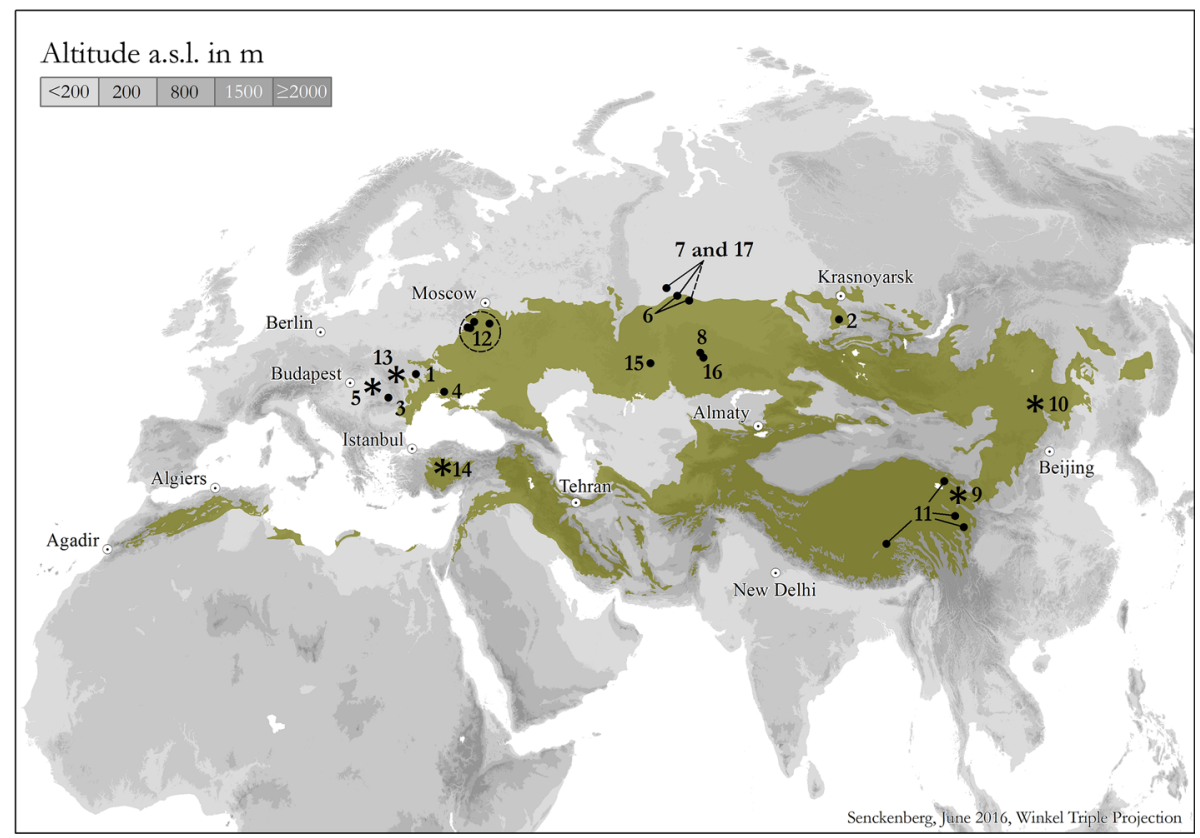

Fig. 1 Simplified map of the Palaearctic steppe biome (with main steppe ecoregions after Wesche et al. 2016) with localisation of the studies included in this Special Issue: (1) Kuzemko et al. (2016); (2) Polyakova et al. (2016); (3) Sutcliffe et al. (2016); (4) Dembicz et al. (2016); (5) Kajtoch et al. (2016); (6) Weking et al. (2016); (7) Mathar et al. (2016); (8) Lameris et al. (2016); (9) Wang and Wesche (2016); (10) Addison and Greiner (2016); (11) Niu et al. (2016); (12) Novenko et al. (2016); (13) Deák et al. (2016); (14) Ambarlı et al. (2016); (15) Kamp et al. (2016); (16) Brinkert et al. (2016); (17) Kämpf et al. (2016). Reviews summarising data across countries are indicated by large asterisks (i.e. 5, 9, 10, 13, 14; numbers indicate approximate geographical centre for respective region of interest) 
large-scale conversion after the Second World War (Kamp et al. 2016). Widespread conversions resulted in steppes being one of the most threatened grassland types in the world; for example, about $57 \%$ of the pristine Eurasian steppes on Chernozem soils were destroyed or degraded (Chibilev 1998). The proportion of steppe converted into cropland decreases from West to East across Eurasia: while in Ukraine 92-95 \% of the pristine steppes have been ploughed, large, unconverted areas remain in Kazakhstan. In Turkey, more than $56 \%$ of the natural steppe and steppe forest area has been lost (Ambarli et al. 2016,), but in contrast in Mongolia, hardly any steppe has been converted to cropland, and in Chinese Inner Mongolia approx. $70 \%$ of natural steppes remains. (Sudnik-Wójcikowska and Moysiyenko 2012; Wesche et al. 2016; White et al. 2000). However, in the unconverted steppes, overgrazing is often an equally serious threat (Wesche et al. 2016). According to the Millennium Ecosystem Assessment (World Resources Institute 2005), “Temperate grasslands, savannas and shrublands" (whose biggest share is the Palaearctic steppes) are unparalleled by any other biome worldwide in the combination of historical and ongoing habitat loss. This high threat level of the Palaearctic steppes and their vast importance for biodiversity stress the need for their conservation and restoration.

This extraordinary conservation relevance, however, is not reflected by an equally good knowledge on distribution and ecology of the steppe bacteria, fungi, plants, and animals and the ecosystem processes of the biome: Research on grassland ecology and conservation is rather focussed on semi-natural grasslands in Europe (see Dengler et al. 2014), the North American prairies or tropical savannas. National research traditions, and the political barriers during the cold war of the 1950s into the 1970s resulted in knowledge on Palaearctic steppes being largely published in national languages in works difficult to obtain, and thus being hardly accessible to an international readership. Attempts to summarise existing knowledge and research on Palaearctic steppes beyond national borders and open them to an international platform are thus timely.

This Special Issue of Biodiversity and Conservation, "Palaearctic steppes: ecology, biodiversity and conservation" aims at providing an overview of current research on ecology and biodiversity for an international audience. We also aim to showcase that steppes harbour high levels of biome-restricted biodiversity, whose endangerment by human-induced degradation and habitat loss is continuing. The Special Issue was initiated by the Eurasian Dry Grassland Group (EDGG; see Box 1; Vrahnakis et al. 2013) during its 11th international conference in Tula, Russia, in June 2014. While previous EDGG Special Issues (e.g. Dengler et al. 2014; Habel et al. 2013; Janišová et al. 2011) were mostly focused on the semi-natural (dry) grasslands of Europe, with only very few contributions from natural steppes being included, here we devote an entire journal issue to the Palaearctic steppe biome to highlight its poor international recognition as a globally important and highly threatened ecosystem. Our initiative extends and builds on a recent book with a similar focus (Werger and van Staalduinen 2012).

This Special Issue contains 17 research articles and reviews, involving around 100 authors, and a comprehensive synthesis paper (Wesche et al. 2016). The studies are spread across the Palaearctic steppe biome (Fig. 1). Two contributions (Kajtoch et al. 2016; Sutcliffe et al. 2016) largely refer to semi-natural and extrazonal dry grasslands outside the steppe biome, addressing processes in these steppe-like grasslands that are also relevant for the natural steppes and can partly be connected to past situations when the respective study areas still belonged to the steppe biome. 
Box 1 The Eurasian Dry Grassland Group

The Eurasian Dry Grassland Group (EDGG, formerly the European Dry Grassland Group) is an official working group of the International Association for Vegetation Science (IAVS) and was founded in 2008. The EDGG is a network of more than 1,000 researchers and conservationists from 60 countries interested in Palaearctic natural and semi-natural grasslands. The most important activities of the EDGG include ones to: (1) coordinate scientific and policy-related actions in grassland research, conservation and restoration in the whole Palaearctic realm; (2) facilitate the trans-national communication between researchers, site managers, policy and decision makers; (3) promote the development of databases for grassland classification, and of best-practice approaches to conservation and restoration; (4) organise annual conferences (the Eurasian Grassland Conference, EGC) and field workshops; and (5) synthesise current knowledge in Special Features of international journals. The EDGG also publishes the open-access Bulletin of the Eurasian Dry Grassland Group four times a year. Everybody who is interested in natural and semi-natural grasslands in the Palaearctic realm is invited to join, free of charge. Further information can be found on the homepage of EDGG (http://www.edgg.org/).

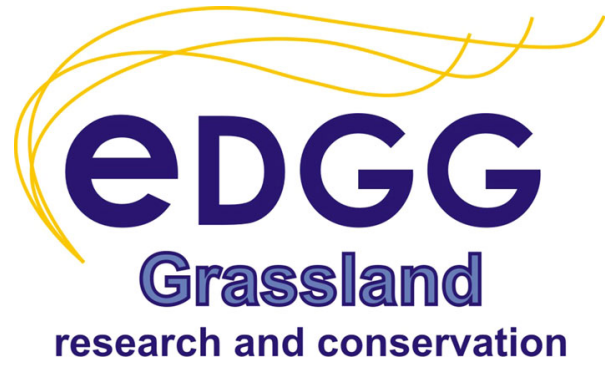

Here, we introduce the individual articles, grouped into the main topic areas of: (1) patterns and drivers of biodiversity; (2) land-use changes and land management; and (3) conservation status, threats, and restoration.

\section{Patterns and drivers of biodiversity}

Semi-natural Palaearctic grasslands are known to be extraordinarily phyto-diverse at small spatial scales, including most of the known "world records" of vascular plant species richness at grain sizes below $100 \mathrm{~m}^{2}$ (Wilson et al. 2012; Dengler et al. 2016). Since they resemble ecologically and floristically the meadow steppes of the forest steppe zone in Eastern Europe and Middle Asia one might wonder why equally high or even higher small-scale richness values are not found in the natural meadow steppes. This Special Issue contains two contributions that applied standardised EDGG multi-scale phytodiversity sampling (Turtureanu et al. 2014) for the first time in natural steppe vegetation: Kuzemko et al. (2016) in Central Podolia, Ukraine, a part of the forest-steppe zone of the European steppe region, and Polyakova et al. (2016) for Khakassia, Russia, at the transition from the Middle Asian to the Mongolian region. Both author teams found high vascular plant species richness across spatial scales, with maxima, however, that were below the maxima in semi-natural grasslands of Central Europe. Taking research data from Western Siberia (Mathar et al. 2016) and Southern Ukraine (Dembicz et al. 2016) into account, the maximum vascular plant species richness for $100 \mathrm{~m}^{2}$ plot size decreases from Central Europe (133) over Khakassia (94), Central Podolia (86), and Southern Ukraine (73) to Western Siberia (54). The reasons for this unexpected pattern as well as some interesting findings with regard to scale dependence call for further data from other regions and their combined analysis. 
Two further projects analysed, within an island-biogeographic framework, the effect of local and landscape parameters on plant species diversity in isolated dry grassland patches in Transylvania, Romania (Sutcliffe et al. 2016), and kurgans in Southern Ukraine (Dembicz et al. 2016). In both areas, refuges for steppe vegetation are found within landscapes largely converted to cropland. Both studies found a strong top-down regulation of species richness, that is when a plot of defined size was located within a larger dry grassland/steppe patch and thus the species pool of the patch was presumably bigger, the richness on plots of 1 and $100 \mathrm{~m}^{2}$ (Ukraine) and $10 \mathrm{~m}^{2}$ (Transylvania) was higher as well. Such a strong species-pool effect within otherwise identical habitats has rarely been shown before. However, the mechanisms in the two regions seem to be different as in Transylvania mainly ruderal species became more diverse on plots located in larger grassland patches, while in Ukraine these were mainly steppe specialists.

Kajtoch et al. (2016), reviewed a comprehensive set of studies that analysed genetic diversity patterns of 38 typical steppe taxa, both animals and plants, at the western margin of the continuous steppe biome. While the genetic patterns showed various taxon-specific peculiarities, the authors concluded from the relative genetic distinctness of isolated populations in the Pannonian region and in steppe-like grasslands in the Czech Republic, Poland, or Germany, which are normally considered as semi-natural, that many of these species may well have survived there during glaciations and did not just reach there after humans started to open the landscape.

\section{Land-use change and land management}

During the past century, land use and management of the Palaearctic steppes changed substantially. As in European non-steppe grasslands, conversion to arable lands, fragmentation, biodiversity loss by degradation, and the transition from extensive management to intensive use, were the main threats (Dengler et al. 2014; Wesche et al. 2016). The most important drivers behind these changes were ploughing during and after World War II, the modern agricultural revolution, and country-level policies such as the Virgin Lands Campaign of the Soviet Union targeted at maximising agricultural yield in the competitive global economy.

More recently, some trends were reversed, namely, cropland abandonment and decreasing land-use intensity in marginal lands occurred in parts of the steppe after intensification in productive plains. These trends were especially pronounced in the Middle Asian steppes, where the collapse of the Soviet Union in 1991 triggered large-scale agricultural change (Kamp et al. 2016; Wesche et al. 2016). The consequences of both agricultural expansion and intensification as well as cropland abandonment on populations of plant and animal communities are discussed in several papers in the Special Issue (e.g. Lameris et al. 2016; Weking et al. 2016).

Weking et al. (2016) showed that, for the Western Siberian forest-steppe, both used and abandoned croplands can provide suitable habitat for Orthoptera (grasshoppers and crickets). The authors concluded that abandoned croplands have a high potential for colonisation and rapid recovery of species-rich orthopteran communities 14 years after abandonment. Low-intensity grazing and hay making were found to support specialist species, and an increase in landscape heterogeneity was beneficial to these insects. This is in line with the findings of Buri et al. (2013), Humbert et al. (2012) and Mathar et al. (2016) for plant community composition and diversity patterns of grassland in the Western Siberian forest steppe. The joint analysis of local site conditions, functional traits, and management in relation to the surrounding landscape revealed that beside the general 
differences in community structure, there are major effects of land use and landscape-scale habitat transformation on the local plant diversity. Never ploughed large meadow steppe patches were characterised by the highest plant species richness and might therefore be used as reference sites in future restoration measures.

Lameris et al. (2016) analysed the population-level consequences of large-scale agricultural abandonment on birds, using the Black Lark (Melanocorypha yeltoniensis), endemic to the steppes of Kazakhstan and fringing regions of Russia, as a model species. In abandoned croplands high densities were reached, but breeding success was low. Based on these findings, Lameris et al. (2016) discuss the potential of abandoned cropland to act as an ecological trap for steppe birds.

Wang and Wesche (2016) evaluate the influence of grazing pressure on vegetation and soil indicators along a grazing intensity gradient based on an extensive review of the scattered Chinese literature. They found that the values of most indicators decreased with increasing grazing intensity, with the exception of soil $\mathrm{pH}$, bulk density, and below-ground biomass, which all increased. Their overview suggests that local abiotic conditions need to be considered when evaluating the effects of grazing because the local environment and the climate interact with grazing intensity. These authors argue that spatio-temporal environmental variation and traditional knowledge of pastoralists should be integrated into local-level management decisions. These assumptions are also supported by Addison and Greiner (2016), who analysed the payment for ecosystem services (PES) schemes in the published literature with a social-ecological system (SES) framework. They found that this approach enabled a detailed and critical diagnosis of the social, economic and environmental impacts of PES-style policy interventions in a complex social-ecological system such as the Eurasian steppe. In line with the conclusions of the former paper's assumptions, this review explicitly identified the importance of micro-economics and cultural values for the design and viability of "payment for ecosystem services" schemes.

Niu et al. (2016) stress the importance of analyses based on plant functional traits in the evaluation of grazing effects on rangeland biodiversity. Based on the analysis of five leaf traits, they suggest that in Tibetan alpine meadows grazing tends to increase the competition among plant species for soil phosphorus, but decreases the competition for light, resulting in an increase in the functional richness of grazed plant communities. They highlight that the potential importance of grazing is that it mediates the competition for multiple resources in the ecosystems they studied, which should be carefully analysed in the planning of sustainable land use.

Novenko et al. (2016) developed a novel view on land use and management in the European forest-steppe zone, based on detailed reconstructions of Mid and Late Holocene vegetation and climate dynamics. They showed that the current forest cover in the form of small patches is a result of high anthropogenic pressures in the past four centuries. Furthermore, climate change will provide competitive advantages to woodlands at the expense of grasslands in the forest-steppe ecotone. Thus their findings underlined the necessity of the preservation of existing grasslands.

\section{Conservation status, threats and restoration}

Temperate grasslands, including Palaearctic steppes, are the most threatened and the least protected terrestrial habitats in the world (Davis et al. 1995; Hoekstra et al. 2005; World Resources Institute 2005). Grasslands host significant levels of biodiversity in human- 
mediated landscapes (Gibson 2009). Therefore, conservation and restoration of grassland biodiversity, especially in agricultural landscapes, have been identified as priorities (Dengler et al. 2014; Török et al. 2011). The proportion of protected areas is higher than $10 \%$ in the Palaearctic steppes, but varies largely across regions (Wesche et al. 2016). The identified threats to steppes have not affected the whole biome evenly; priorities in steppe conservation and restoration are therefore likely to vary regionally (Wesche et al. 2016).

Deák et al. (2016) and Dembicz et al. (2016) show that in the European part of the steppe and forest steppe zone, only small, fragmented patches of steppe remained. They identified a need for the restoration of steppe habitat to increase landscape-scale connectivity. Deák et al. (2016) suggest that steppe vegetation can persist even in heavily degraded landscapes at certain structures, such as kurgans, road verges, and field margins, which can act as sources of species (i.e. donor sites for restoration). Ambarl1 et al. (2016) considered the biodiversity of steppes in the Anatolian Biogeographic Region and concluded that the current area of protected sites, comprising only $1.5 \%$ of that region, is insufficient to preserve its' biodiversity. They developed a detailed to-do list for conservation authorities, which has the potential to mitigate further biodiversity loss and help to facilitate steppe restoration.

Two papers of the Special Issue focus on steppe conservation in Kazakhstan. Kamp et al. (2016) conducted a threat analysis based on a horizon scanning approach. They suggest that the highest-ranked threats to steppe habitats and species are related to changes in land use, the direct persecution of wildlife, and rapid infrastructure development, which has in turn been triggered by rapid economic development and population growth. They also identified some new threats to steppe biodiversity in the form of habitat loss related to a potential future increase in the installation of photovoltaic and wind power stations, to the effects of climate change and changes in agriculture. Brinkert et al. (2016) analysed the restoration potential of abandoned arable land with a focus on the role of grazing. Their results suggest that even after 15-20 years of abandonment, steppe vegetation has not fully recovered on abandoned fields, but the recovery process can be accelerated by particular levels of grazing.

In contrast to Europe and parts of Kazakhstan, where a high proportion of the steppes had been converted to cropland, arable farming remained patchy across the Western Siberian forest steppe as many areas are too wet for farming. In consequence, a patchy mixture of meadow steppes, croplands, wetlands, and birch forests, is still found there (Kämpf et al. 2016). Agricultural abandonment had positive consequences for particular plants and the vegetation as a whole ; the vegetation of arable land comprised mostly widely distributed weeds. Assuming an increasing demand for food and fibre, land-use strategies to reconcile biodiversity conservation and food production both for Western Siberia (Kämpf et al. 2016) and for Kazakhstan (Kamp et al. 2015) might rather promote a sustainable intensification of existing croplands rather than a new expansion of cropland into currently abandoned areas.

Acknowledgments The Special Issue was planned by all authors of this Editorial and coordinated by J.D. P.T. led the writing of this Editorial to which all authors contributed. We thank all members of the Eurasian Dry Grassland Group (EDGG), particularly our colleagues in the Tula region of Russia, who made the conference possible that gave rise to this Special Issue. We are also indebted to the 100 authors and numerous reviewers of this Special Issue, Editor-in-Chief David L. Hawksworth, and the whole team of Biodiversity and Conservation to make this Special Issue possible. Aiko Huckauf kindly polished our English, while EDGG supported the linguistic editing here and in many of the Special Issue articles. 


\section{References}

Addison J, Greiner R (2016) Applying the social-ecological systems framework to the evaluation and design of payment for ecosystem service schemes in the Eurasian steppe. Biodivers Conserv. doi:10.1007/ s10531-015-1016-3

Ambarlı D, Zeydanlı US, Balkız Ö, Aslan S, Karaçetin E, Sözen M, Ilgaz Ç, Gürsoy Ergen A, Lise Y, Demirbaş Çağlayan S, Welch HJ, Welch G, Turak AS, Bilgin CC, Özkil A, Vural M (2016) An overview of biodiversity and conservation status of steppes of the Anatolian Biogeographical Region. Biodivers Conserv. doi:10.1007/s10531-016-1172-0

Bredenkamp GJ, Spada F, Kazmierczak E (2002) On the origin of northern and southern hemisphere grasslands. Plant Ecol 163:209-229. doi:10.1023/a:1020957807971

Brinkert A, Hölzel N, Sidorova TV, Kamp J (2016) Spontaneous steppe restoration on abandoned cropland in Kazakhstan: grazing affects successional pathways. Biodivers Conserv. doi:10.1007/.s10531-0151020-7

Buri P, Arlettaz R, Humbert JY (2013) Delaying mowing and leaving uncut refuges boosts orthopterans in extensively managed meadows: evidence drawn from field-scale experimentation. Agric Ecosyst Environ 181:22-30. doi:10.1016/j.agee.2013.09.003

Chibilev AA (1998) Basics of steppe science (in Russian). Publisher House DIMUR, Orenburg

Davis SD, Heywood VH, Hamilton AC (eds) (1995) Centres of plant diversity: a guide and strategy for their conservation, vol 2., Asia, Australasia and the PacificIUCN, Gland

Deák B, Tóthmérész B, Valkó O, Sudnik-Wójcikowska B, Moysiyenko II, Bragina TM, Apostolova I, Dembicz I, Bykov NI, Török P (2016) Cultural monuments and nature conservation: a review of the role of kurgans in the conservation and restoration of steppe vegetation. Biodivers Conserv. doi:10. 1007/s10531-016-1081-2

Dembicz I, Moysiyenko II, Shaposhnikova A, Vynokurov D, Kozub Ł, Sudnik-Wójcikowska B (2016) Isolation and patch size drive specialist plant species density within steppe islands: a case study of kurgans in southern Ukraine. Biodivers Conserv. doi:10.1007/s10531-016-1077-y

Dengler J, Janišová M, Török P, Wellstein C (2014) Biodiversity of Palaearctic grasslands: a synthesis. Agric Ecosyst Environ 182:1-14. doi:10.1016/j.agee.2013.12.015

Dengler J, Biurrun I, Apostolova I, Baumann E, Becker T, Becker U, Berastegi A, Boch S, Cancellieri L, Dembicz I, Didukh YP, Dolnik C, Ermakov N, Filibeck G, Garcia-Mijangos I, Giusso del Galdo G, Guarino R, Janišová M, Jaunatre R, Jensen K, Jeschke M, Kącki Z, Kozub Ł, Kuzemko AA, Löbel S, Pedashenko H, Polyakova M, Ruprecht E, Szabó A, Vassilev K, Velev N, Weiser F (2016) Scaledependent plant diversity in Palaearctic grasslands: a comparative overview. Bull Eurasian Dry Grassl Group 31:12-26

Gibson JD (2009) Grasses and grassland ecology. Oxford University, New York

Habel JC, Dengler J, Janišová M, Török P, Wellstein C, Wiezik M (2013) European grassland ecosystems: threatened hotspots of biodiversity. Biodivers Conserv 22:2131-2138

Hoekstra JM, Boucher TM, Ricketts TH, Roberts C (2005) Confronting a biome crisis: global disparities of habitat loss and protection. Ecol Lett 8:23-29. doi:10.1111/j.1461-0248.2004.00686.x

Humbert JY, Ghazoul J, Richner N, Walter T (2012) Uncut grass refuges mitigate the impact of mechanical meadow harvesting on orthopterans. Biol Conserv 152:96-101. doi:10.1016/j.biocon.2012.03.015

Janišová M, Bartha S, Kiehl K, Dengler J (2011) Advances in the conservation of dry grasslands-introduction to contributions from the 7th European dry grassland meeting. Plant Biosyst 145:507-513. doi:10.1080/11263504.2011.603895

Kajtoch Ł, Cieślak E, Varga Z, Paul W, Mazur MA, Sramkó G, Kubisz D (2016) Phylogeographic patterns of steppe species in Eastern Central Europe: a review and the implications for conservation. Biodivers Conserv. doi:10.1007/s10531-016-1065-2

Kamp J, Urazaliev R, Balmford A, Donald PF, Green RE, Lamb AJ, Phalan B (2015) Agricultural development and the conservation of avian biodiversity on the Eurasian steppes: a comparison of landsparing and land-sharing approaches. J Appl Ecol 52:1578-1587

Kamp J, Koshkin MA, Bragina TM, Katzner TE, Milner-Gulland EJ, Schreiber D, Sheldon R, Shmalenko A, Smelansky I, Terraube J, Urazaliev R (2016) Persistent and novel threats to the biodiversity of Kazakhstan's steppes and semi-deserts. Biodivers Conserv. doi:10.1007/s10531-016-1083-0

Kämpf I, Mathar W, Kuzmin I, Hölzel N, Kiehl K (2016) Post-Soviet recovery of grassland vegetation on abandoned fields in the forest steppe zone of Western Siberia. Biodivers Conserv. doi:10.1007/s10531016-1078-x

Kuzemko AA, Steinbauer MJ, Becker T, Didukh YP, Dolnik C, Jeschke M, Naqinezhad A, Ugurlu E, Vassilev K, Dengler J (2016) Patterns and drivers of phytodiversity of steppe grasslands of Central Podolia (Ukraine). Biodivers Conserv. doi:10.1007/s10531-016-1060-7 
Lameris TK, Fijen TPM, Urazaliev R, Pulikova G, Donald PF, Kamp J (2016) Breeding ecology of the endemic Black Lark Melanocorypha yeltoniensis on natural steppe and abandoned croplands in postSoviet Kazakhstan. Biodivers Conserv. doi:10.1007/s10531-015-1041-2

Mathar WP, Kämpf I, Kleinebecker T, Kuzmin I, Tolstikov A, Tupitsin S, Hölzel N (2016) Floristic diversity of meadow steppes in the Western Siberian Plain: effects of abiotic site conditions, management and landscape structure. Biodivers Conserv. doi:10.1007/s10531-015-1023-4

Niu K, He J-S, Zhang S, Lechowicz MJ (2016) Grazing increases functional richness but not functional divergence in Tibetan alpine meadow plant communities. Biodivers Conserv. doi:10.1007/s10531-0150960-2

Novenko EY, Tsyganov AN, Rudenko OV, Volkova EV, Zuyganova IS, Babeshko KV, Olchev AV, Losbenev NI, Payne RJ, Mazei YA (2016) Mid- and late-Holocene vegetation history, climate and human impact in the forest-steppe ecotone of European Russia: new data and a regional synthesis. Biodivers Conserv. doi:10.1007/s10531-016-1051-8

Polyakova MA, Dembicz I, Becker T, Becker U, Demina ON, Ermakov N, Filibeck G, Guarino R, Janišová M, Jaunatre R, Kozub Ł, Steinbauer MJ, Suzuki K, Dengler J (2016) Scale- and taxon-dependent patterns of plant diversity in steppes of Khakassia, South Siberia (Russia). Biodivers Conserv. doi:10. 1007/s10531-016-1093-y

Sudnik-Wójcikowska B, Moysiyenko II (2012) Kurgans in the 'Wild Field'-a cultural heritage and refugium of the Ukrainian steppe. Wydawnictwa Uniwersytetu Warszawskiego, Warszawa

Sutcliffe LME, Germany M, Becker U, Becker T (2016) How does size and isolation affect patches of steppe-like vegetation on slumping hills in Transylvania, Romania? Biodivers Conserv. doi:10.1007/ s10531-016-1108-8

Török P, Vida E, Deák B, Lengyel S, Tóthmérész B (2011) Grassland restoration on former croplands in Europe: an assessment of applicability of techniques and costs. Biodivers Conserv 20:2311-2332. doi:10.1007/s10531-011-9992-4

Turtureanu PD, Palpurina S, Becker T, Dolnik C, Ruprecht E, Sutcliffe LME, Szabó A, Dengler J (2014) Scale- and taxon-dependent biodiversity patterns of dry grassland vegetation in Transylvania (Romania). Agric Ecosyst Environ 182:15-24. doi:10.1016/j.agee.2013.10.028

Vrahnakis MS, Janišová M, Rūsinna S, Török P, Venn S, Dengler J (2013) The European Dry Grassland Group (EDGG): stewarding Europe's most diverse habitat type. In: Baumbach H, Pfützenreuter S (eds) Steppenlebensräume Europas-Gefährdung, Erhaltungsmaßnahmen und Schutz. Thüringer Ministerium für Landwirtschaft, Forsten, Umwelt und Naturschutz, Erfurt, pp 417-434

Wang Y, Wesche K (2016) Vegetation and soil responses to livestock grazing in Central Asian grasslands: a review of Chinese literature. Biodivers Conserv. doi:10.1007/s10531-015-1034-1

Weking S, Kämpf I, Mathar W, Hölzel N (2016) Effects of land use and landscape patterns on Orthoptera communities in the Western Siberian forest steppe. Biodivers Conserv. doi:10.1007/s10531-016-1107-9

Werger MJA, van Staalduinen MA (eds) (2012) Eurasian steppes. Ecological problems and livelihoods in a changing world. Springer, Dordrecht

Wesche K, Ambarlı D, Kamp J, Török P, Treiber J, Dengler J (2016) The Palaearctic steppe biome: a new synthesis. Biodivers Conserv. doi:10.1007/s10531-016-1214-7

White RP, Murray S, Rohweder M (2000) Pilot analysis of global ecosystems: grassland ecosystems. World Resources Institute, Washington

Wilson JB, Peet RK, Dengler J, Pärtel M (2012) Plant species richness: the world records. J Veg Sci 23:796-802. doi:10.1111/j.1654-1103.2012.01400.x

World Resources Institute (ed) (2005) Ecosystem and human well-being: biodiversity synthesis-A report of the Millennium Ecosystem Assessment. World Resources Institute, Washington 